\title{
Conservation issues and chemical study of the causes of alteration of a part of the Stave Church in Hopperstad (Norway)
}

\author{
Marit Lehne ${ }^{*}$, Sara Mantellato ${ }^{2}$, Asel Maria Aguilar Sanchez ${ }^{2}$ and Francesco Caruso ${ }^{1,3}$
}

\begin{abstract}
An unidentified white substance was observed on the exterior parts of the southern side of Hopperstad Stave Church, located in Vik in Sogn and Fjordane (Norway). One of the 28 remaining stave churches in the country, Hopperstad Stave Church was built between 1130 and 1150 and it constitutes an important part of Norwegian cultural heritage. Such a substance was observed for the first time in 2009 and serious concerns about its harmfulness and origin have been raised. A comprehensive study involving non-invasive (portable XRF) and micro-invasive analyses (SEM, ICP-OES, TOC) was undertaken to investigate the physico-chemical nature of this white substance. Tarring, salt migration from the nearby cemetery, atmospheric agents, leakages from the roof, biological infestation, previous treatments with pesticides are among the possible causes of the phenomenon. This work-employing a unique approach in conservation/conservation science-indicates that the white substance is mainly inorganic and crystalline. It was, therefore, possible to exclude some of the possible causes, hence, clarifying some of the conservation issues of the church.
\end{abstract}

Keywords: Salts, Tarring, Middle ages, Portable XRF, ICP-OES, SEM, TOC

\section{Introduction}

As the name suggests, stave churches are named after the use of staves as fundamental building elements for their walls. In the Middle ages, such a design was common across the whole Northern Europe, but, as of today, stave churches are found only in three countries: Norway, Sweden and United Kingdom. With only 28 remaining (out of the original 2000), stave churches represent an important part of the Norwegian built heritage and Urnes Stave Church is a UNESCO World Heritage Site [1, 2]. Hopperstad Stave Church is located in the municipality of Vik (county of Sogn and Fjordane) (Fig. 1).

Being built between 1130 and 1150, it is one of Norway's oldest stave churches. Most of the exterior was replaced during a major restoration in the late 1880s. The core building (the nave and choir) is original and most

\footnotetext{
*Correspondence: marit.@@live.no

${ }^{1}$ Institutt for arkeologi, konservering og historie (IAKH), Conservation Studies, Universitetet i Oslo (UiO), Blindern, Postboks 1008, 0315 Oslo, Norway

Full list of author information is available at the end of the article
}

of the interior from the Middle Ages is preserved. The whole exterior of the church is covered with tar. Today, it is a museum church, but is also used for weddings and burials.

\section{Conservation issues and aims of the study}

Hopperstad Stave Church suffers from several alteration and degradation problems, such as rot, leakage and distortion of the building construction and foundation, which have been documented over the past century. The most recent reports are authored by the Norwegian Directorate for Cultural Heritage (RA, Riksantikvaren) $[3,4]$. Among the above-mentioned issues, one of the most peculiar is the formation of a white substance on the surface of localized areas of the church, both indoors and outdoors. The most affected area is the top part of the external southern door and portal of the church (both on the wood and metal) (Fig. 2).

This layer seems to be quite thick and to have a white crust-like appearance on the tarred surface. Besides, there are also some areas inside the church, on untarred wood, which are covered by a thin and powdery white 


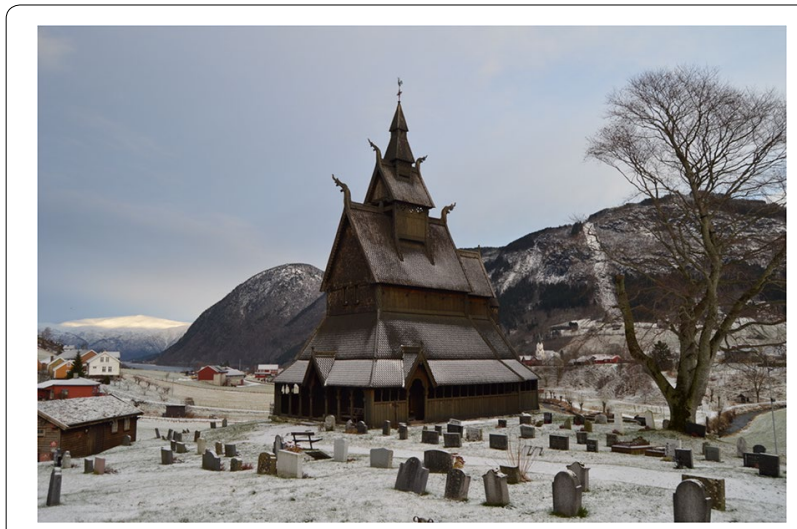

Fig. 1 Hopperstad Stave Church, sited in the municipality of Vik in Sogn and Fjordane (Norway)

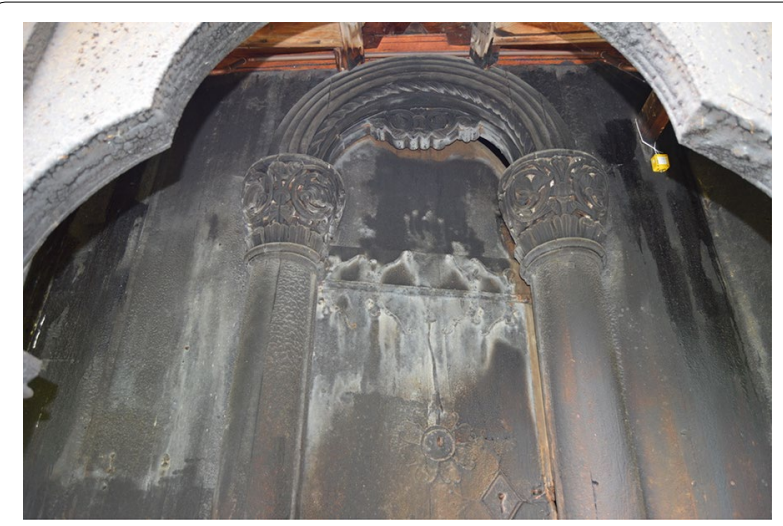

Fig. 2 The southern door and portal of Hopperstad Stave Church, partly covered by a white layer. A data logger, to monitor the temperature and $\mathrm{RH}$, is visible in the upper right part of the picture layer (Fig. 3), showing a different appearance in texture, spread and amount of substance with respect to the layer on the tarred surface.

A white substance was observed on parts of the southern entrance, both inside and outside, for the first time in 2009. Concerns about the white layer on the southern side of the church were raised in 2013 by Anker [5] and later by Olstad and Haugen [6]. Besides being aesthetically unpleasing, the unidentified substance could possibly be harmful for the church's original materials, environment and visitors. The aim of this work is an investigation about the origin of the white substance, trying to find the cause and source of this phenomenon, and assess its harmfulness.

\section{Existing literature and preliminary assessment of the white substance}

The process has included collecting inspection reports, mainly from RA and the National Trust of Norway (Fortidsminneforeningen, section of Oslo). In the archives, it was searched for reports and documentation on Hopperstad that mention surface layers on tarred (or other) surfaces. This included pictures of the church where a similar white layer can be seen, and pictures of the southern wall to see possible changes in amount and spread of the white layer. Reports on maintenance routines and chemicals used on the church were also searched, to see if they could be related to the phenomenon. In addition to the literature/documentation search, information has also been gathered by conversation with people who have-in one way or another-worked with Hopperstad

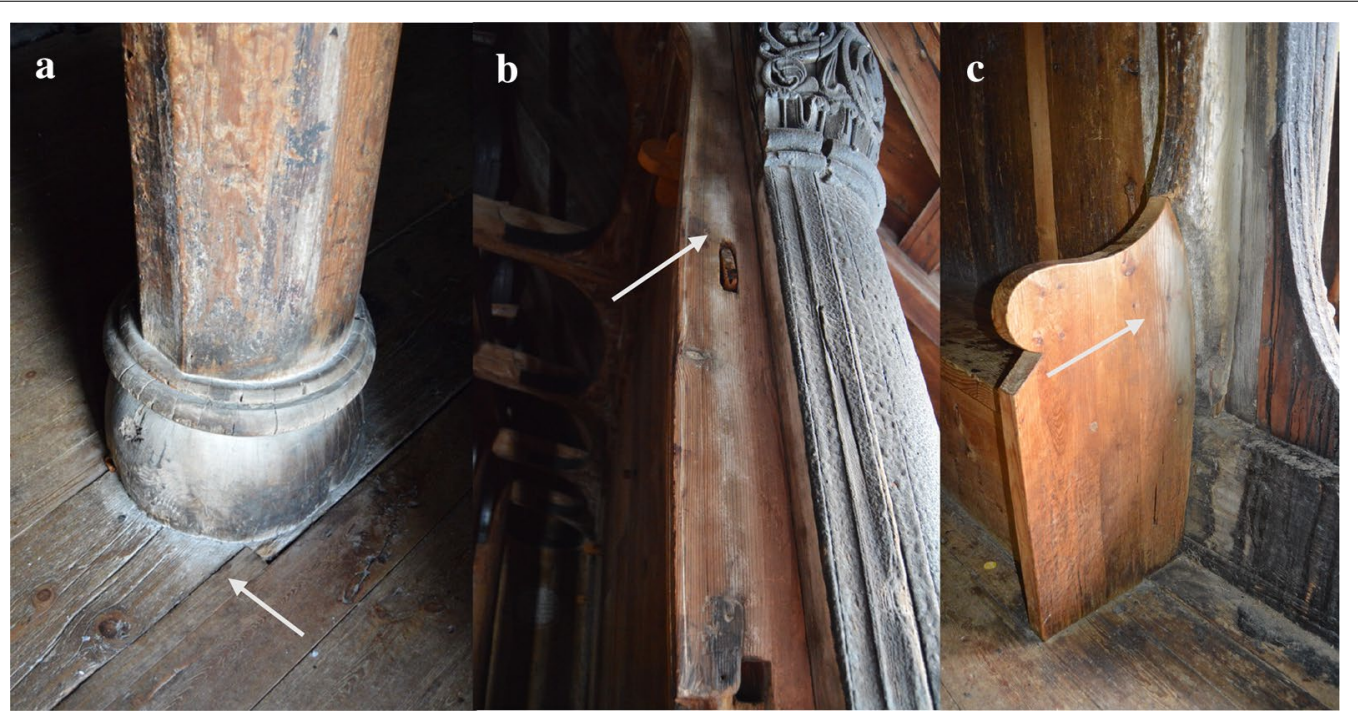

Fig. 3 The stave base and floor of Hopperstad Stave Church with a white layer (image a), indicated by a white arrow. The white layers on the crossbar and bench in images $\mathbf{b}$ and $\mathbf{c}$ are also indicated by white arrows 
Stave Church. The archive material span documents from nineteenth century, handwritten notes by Blix and others, to documents from 2015. However, the layer is considered to be a recently discovered phenomenon. Concerns about it were first raised in 2013. Therefore, only documents from the 1990s on were considered. A summary of the weathering phenomena, the treatments and the repairs regarding Hopperstad Stave Church, from 1963 to 2006, is also reported by Olstad and Haugen [6].

There were many inspections and condition reports that mention different conservation issues at Hopperstad, but not much that could directly be related to the white substance. The issues mostly affected other parts of the church, but not the areas presently affected by the white layer. As mentioned above, the church has suffered from a variety of building and conservation issues. Several examinations have been conducted during the past century. These have included inspections under the floor, the interior and the painted surfaces inside, and assessments of the tar. There have also been assessments of the area surrounding the church.

White surface layers were mentioned a few times in the archives. The term "chalking" (kritting) was used in relation to maintenance routines of tarred surfaces in a "management, operation and maintenance" (FDV, forvaltning, drift og vedlikehold) folder from 1992 at the National Trust of Norway. It is therein stated that a new application of tar is needed when the tar chalks, and the bare wood becomes visible, without any further explanation of what the term "chalking" means. It was also mentioned the use of pigments in tar, but this is not common practice today. Reports from inspections done by RA at Hopperstad in 2001 and 2003 mention the formation of a white surface layer on the tarred wall planks north of the choir [7]. It was concluded that the layer seemed to be harmless and that it disappeared shortly after the application of new tar. There were no traces of the layer during the inspection in 2003 [7] and, therefore, no further investigation was conducted by RA. A white layer was also observed on the inside of the church during an inspection by RA in November 2005 [8]. This was observed up under the roof in the elevated mid room, on the south-east corner stave and $\mathrm{knee}^{1}$, which also had visible rot damage. The surfaces of the stave and knee were described to have bristly wood fibres and a white layer with a salty taste. Samples were also taken and investigated by a private laboratory (Mycoteam AS, Oslo, Norway) without any conclusive results about the white layer [8]. The use of any chemical,

\footnotetext{
${ }^{1}$ Corners and angulated connections in the church construction are strengthened with knees. The knees are typically made of subjects from the transition between the tree root and trunk, where the fibers are strong and bent in angles [9].
}

which was considered relevant for the formation of the white layer, was not mentioned in the archives.

Before analysing the white substance, some suggestions on its nature were advanced. The suggestions were based on visual observations and an internal inspection report from RA [5]. Among these suggestions was microbiological infestation, partly because it seemed that the layer was only present on the surface with the cracks of the tar. Another hypothesis was that the white substance could be a degradation product of the tar, when combined with moisture. In a recent report by the Norwegian Institute for Cultural Heritage Research (NIKU, Norsk institutt for kulturminneforskning) about the preservation of church buildings in a changing climate, the white layer on both the southern and northern portal was allegedly related to moisture damage and degraded tar [6]. It is also therein stated that this type of degradation on tarred surfaces is common when the surface gets worn due to direct water impact. It was concluded that, if the white layer has been caused by moisture, it had to be because of either constant high RH in the air or exposure to liquid water [6]. According to the National Trust of Norway and RA, the rapid degradation of tar on stave churches-especially on surfaces exposed to atmospheric agents-has been a major concern for many years [10]. The main cause of such a degradation is, however, not fully understood.

The idea that the phenomenon could be associated with old and/or new leaks and moisture problems, which have been the case with Hopperstad Stave Church, was also due to a white layer observed on the inside of the church, on the southern side of the nave. A white layer has been observed above a crossbar by the southern entrance and the wall panels with the layer are markedly damper than the adjoining wall panels without a white layer. A similar white layer has been seen on a stave base and the floor, just inside the southern entrance. This could be caused by old moisture damage. Signs of leakage in the gallery entrance, in front of the nave's southern portal, have also been mentioned in inspection reports from Anker [5] or Olstad and Haugen [6]. However, it was not clear if this was an old or new issue.

It was also thought that the layer could be caused by efflorescence of salts. This is a common phenomenon for buildings and can be a result of a previous treatment of the building material $[11,12]$. A previous pesticide treatment was also considered as a possible source. If so, the layer could potentially be harmful for the visitors and environment. In fact, the church had been treated with phosphine, $\mathrm{PH}_{3}$, in 1984 [13]. ${ }^{2}$ This was the only time that the whole church has been treated with pesticides.

\footnotetext{
${ }^{2}$ Hopperstad Stave Church was treated with phosphine because of the infestation by the House Longhorn beetle (Hylotrupes bajulus).
} 

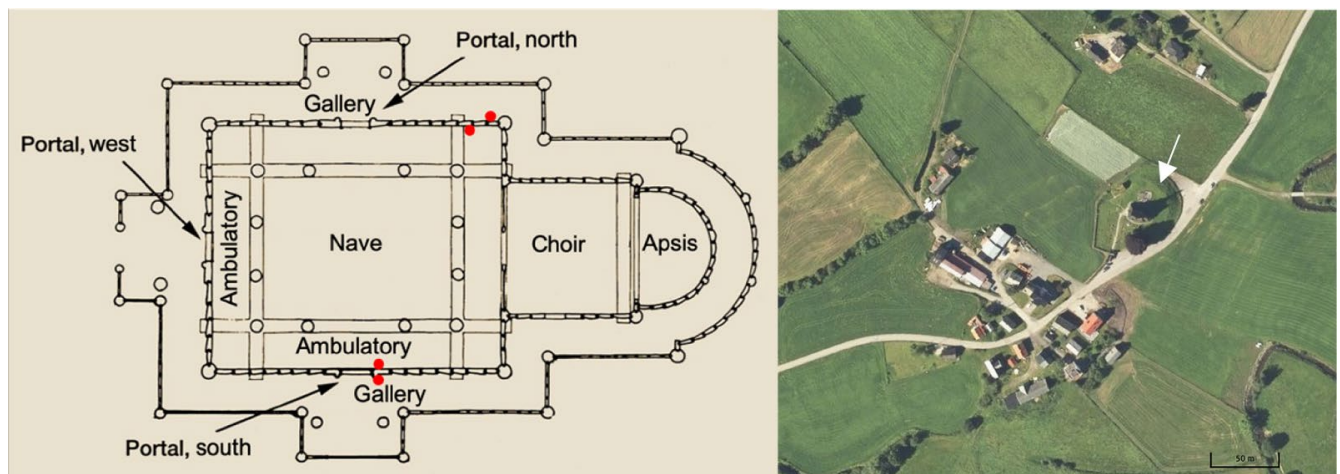

Fig. 4 Plan of the Hopperstad stave Church (left) and its satellite image (right, adapted from the web site of the Norwegian Mapping Authority, Kartverket). In the plan, the position of the data loggers is indicated by red circles

\section{Methods}

The approach for this research has included visual investigations and physico-chemical analyses. The chosen non-invasive and micro-invasive analytical techniques allowed to get as much information as possible in view of the research questions. Portable X-ray fluorescence (XRF) analysis was conducted to get a first indication of the elements present in the white substance. Scanning electron microscopy (SEM) was employed on tiny samples to study the surface morphology of the substance. On the basis of the indications given by the XRF data, selected elements were quantified by inductively coupled plasma-optical emission spectroscopy (ICP-OES). Total organic carbon (TOC) analysis was carried out to measure the amount of organic carbon in each sample. In addition, data loggers were placed on the southern and northern walls of the church to disclose any climatic differences that might explain why the substance is localized on the southern part of the church. For the purposes of this work, it was more important to characterize the white substance from a qualitative point of view.

\section{Climatic monitoring with dataloggers}

Four Tinytag data loggers (Gemini Data Loggers Ltd, Chichester, UK) were placed on the walls inside and outside the church to measure and record the temperature and $\mathrm{RH}$ (Fig. 4). Two loggers were suspended from the beams on the northern wall of the church and two on the southern wall (one inside and one outside, under the ceiling). The southern side is the most affected of the white substance, while the northern side does not have any distinct white layers (there is a visible white layer appearing on the portal above the entrance, but with finer structure than on the southern side). The temperature and RH were recorded each hour. The data loggers were new and calibrated. The monitoring settings and the obtained data were handled with the Tinytag Explorer Windows software (Version 4.7) by Gemini Data Loggers.

\section{Portable X-ray fluorescence}

Portable XRF enables measurements to be taken in situ. It is a non-invasive and non-destructive technique and is, therefore, a widely used technique within the conservation field [14-18]. The technique is used to obtain the elemental composition of different materials, and is capable of analysing a variety of materials, including solids, liquids and thin-films $[18,19]$.

The used XRF instrument was a Thermo Scientific Niton XL3t 950-He handheld XRF (Thermo Fisher Scientific, Oslo, Norway) with a Si-Drift detector (GOLDD+-Geometrically Optimized Large area Drift Detector). Since the nature of the substance was unknown before the measurements, the proprietary "Mining $\mathrm{Cu} / \mathrm{Zn}$ Testing Mode" was used. This mode allows to detect the largest range of elements. Total measurement time was ca. $120 \mathrm{~s}$ for each zone and the instrument switched automatically from main $(\mathrm{Al} / \mathrm{Fe}$ filter, potential: $50 \mathrm{kV}$, maximum current: $40 \mu \mathrm{A}$ ), low (Cu filter, potential: $20 \mathrm{kV}$, maximum current: $100 \mu \mathrm{A}$ ) to high (Mo filter, potential: $50 \mathrm{kV}$, maximum current: $40 \mu \mathrm{A}$ ) and light range filters. The data were collected and organized using the NDTr Windows software by Thermo (NITON Data Transfer Version 7.1 Alpha) and Microsoft Excel. In order to get a complete "view" of all the elements detected by this instrument, the spectra presented in this work were obtained by summing the single ones recorded with the different filters.

A total of 21 XRF measurements were carried out on different surfaces of the church. The measurement locations were selected after visual investigation of the most affected areas. Analyses were conducted inside and outside the southern side, both on affected and unaffected areas to be able to compare the results. The measurements acquired inside the church were on zones made 
of wood without tar, where some areas had a thin layer of fine, powdery white substance. All the measurements taken outside the church were on zones of wood covered with tar layers. The most affected areas had a thick layer of white substance on the surface of the tarred wood.

\section{Sampling for destructive analyses}

For both visual and physico-chemical analysis, small samples of the white substance were taken from the church. However, since the church is a part of Norway's cultural heritage, the quantity of samples that was taken was limited to a minimum amount ( $\lesssim 1 \mathrm{mg}$ ), according to the E.C.C.O. code of ethics for conservation and the AIC's code of ethics and guidelines for practice [20, 21]. A total of seven samples were collected to carry out SEM, ICP-OES and TOC analyses, specifically five samples from the outside (M1, M4-M7) and two from the inside (M2-M3). Descriptions and locations of the samples are presented in Table 1. From the outside of the church, samples were only taken from the white substance and the tar (which gets worn down and needs to be reapplied regularly). From the inside, however, some wood was taken along with the white substance. A pure wood sample of the church was not taken, since a single sample would not have been representative for the whole church. A sample of bird droppings (M1) was also taken from the outside, to determine whether this could be a possible source for the phenomenon. The sample locations were chosen based on the XRF measurement locations but not directly where the XRF readings had been taken. All the samples were scraped directly into clean glass containers with PE lids, using clean scalpel with stainless steel blades for each sample. Extensive photographic documentation was acquired with a Nikon D3200 (Nikon UK Ltd. NUF, Oslo, Norway) before and after the sampling. The samples were stored at room temperature for ca. 9 weeks before analysis.

\section{Scanning electron microscopy}

SEM is an electron microscopy technique that enables the visualization of objects in micro- and nanospace (roughly from $100 \times$ to $100,000 \times$ ) [18, 22, 23]. The technique is used for topographical, morphological, compositional and crystallographic studies. For elemental analysis, SEM can be combined with Energy Dispersive Spectrometry (EDS) [18].

A small fragment of each sample was mounted on metal stubs previously covered with double-sided, carbon tape. High vacuum mode and low voltage $(5 \mathrm{kV})$ were first used on sample M1 (bird dropping) to get its surface details. Because of the low conductivity of the sample, the instrument was switched to low vacuum mode (secondary electrons) and a large field detector (LFD) was used for the rest of the samples. The chamber was filled with water vapor to make the samples more conductive and improve the quality of the images.

Inductively coupled plasma-optical emission spectrometry ICP-OES is an instrumental analytical technique used to obtain qualitative and quantitative elemental information from liquid solutions. It allows quantification of elemental traces down to $10 \mathrm{ng} / \mathrm{L}$ for some selected elements $[24,25]$.

Before extraction of the samples, each sample was ground to a fine powder with agate mortar and pestle. The pulverized samples were put into PE containers, which had been labelled and individually weighed on an analytical balance. Samples M4, M5, M6 and M7 were very sticky during grinding because of the probable high content of tar (indicated by the strong smell), which made them very difficult to be put in the containers. The containers with the pulverized samples were then weighed and the content treated with ca. $10 \mathrm{~mL}$ of ultrapure water, UPW $(\rho=18.2 \mathrm{M} \Omega \mathrm{cm}$, TOC around 1-2 ppb. Dispensed by a Milli-Q A+ water purification system from MilliPore, Merck \& Cie, Schaffhausen, Switzerland). The filled containers were then weighed once again. The containers were placed in an ultrasonic bath (Bandelin Sonorex RK100H, BANDELIN electronic GmbH \& Co, KG, Berlin, Germany), for $2 \mathrm{~h}$, and left in the water over night. The water of the ultrasonic bath was at a temperature of around $40{ }^{\circ} \mathrm{C}$. The samples were then filtered in sterile plastic syringes connected to disposable membrane filters, $0.45 \mu \mathrm{m}$ CHROMAFIL Xtra H-PTFE-45/35 by Macherey-Nagel AG (Macherey-Nagel AG, Oensingen, Switzerland) into new, labelled PE containers. For the dilution of the filtered samples, ca. $20 \mathrm{~g}$ of nitric acid $\left(\mathrm{HNO}_{3}\right)$ (TraceSELECT $\leq 96 \%$. Sigma-Aldrich Chemie GMbH, Buchs, Switzerland) 2\% (w/w) in UPW was poured into new plastic containers while on the analytical balance. The containers had been labelled and weighed without lids in advance. While on the balance, ca. $2 \mathrm{~g}$ of the filtered sample solution was poured in the container with the nitric acid using a clean plastic pipette.

A Thermo Scientific iCAP 6300 Dual View ICP-OES (Thermo Fisher Scientific Inc., Waltham, MA, USA) with a CETAC ASX-260 autosampler (CETAC, Omaha, NE, USA) was used for the analysis. Its operating conditions are reported in Table 2.

Both the standard solution and the reference (RM) one contained aluminium, calcium, copper, iron, potassium, magnesium, sodium, phosphorus, sulfur, silicon and zinc. The elements in the standard solution had a concentration of $2 \mathrm{mg} / \mathrm{L}$, whereas, in the RM, they had a concentration of $1 \mathrm{mg} / \mathrm{L}$. 


\section{Table 1 Sampling locations}

\section{Name of sample}

M1 Bird droppings, outside

ken from accumulation of bird droppings on an edge on the outside wall, left of the southern entrance

M2 Floor, inside

M4 Portal, outside

M5 Portal, outside
Taken from above the crossbar

Taken from the floor close to the stave base, in the nearby of the southern entrance

Taken from the southern portal, on the right side, above the entrance on the carvings (spiral decoration)

Taken from the middle of the southern portal, above the entrance

\section{Picture}
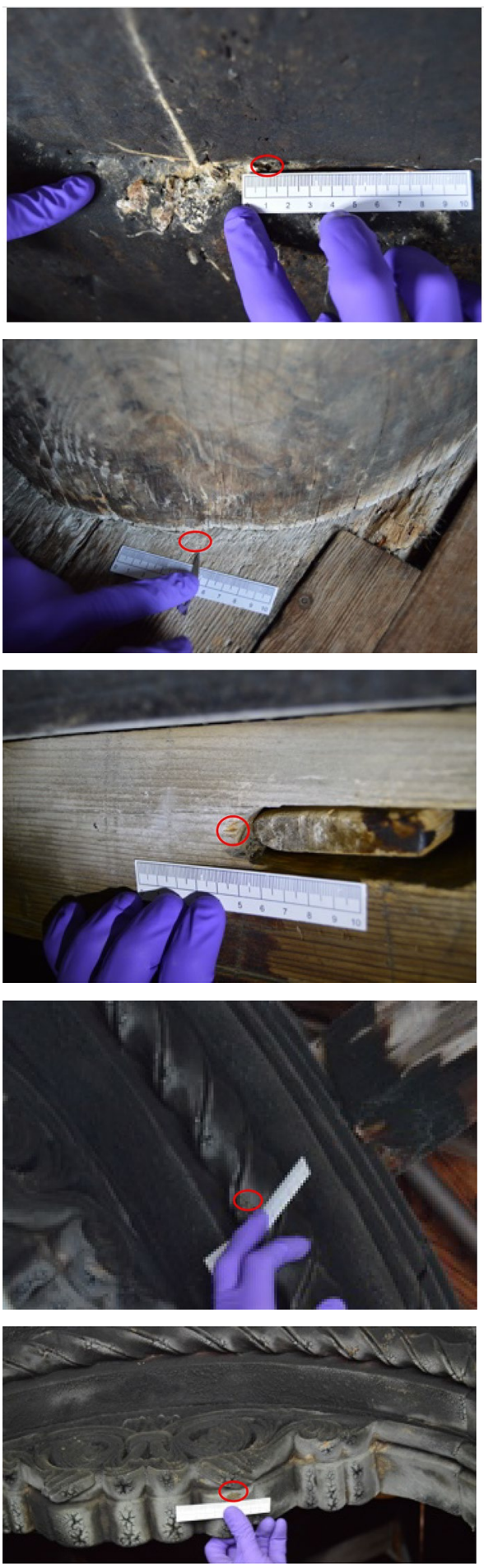
Table 1 (continued)

\begin{tabular}{|c|c|c|}
\hline Name of sample & Description & Picture \\
\hline M6 Door, outside & Taken from the southern door, below a wrought iron decoration & \\
\hline M7 Door, outside & Taken from the southern door, below a wrought iron decoration & \\
\hline
\end{tabular}

Table 2 Operating conditions for the ICP-OES measurements with the iCAP 6300 Dual View

\begin{tabular}{|c|c|}
\hline Operating condition/instrument part & Value/type \\
\hline Effective focal length & $383 \mathrm{~nm}$ \\
\hline Spectral range & $166-847 \mathrm{~nm}$ \\
\hline Detector & CID86 chip (charge injection device) \\
\hline RF generator & 27.12 MHz solid state \\
\hline Plasma viewing & Dual \\
\hline Plasma and shear gas & Argon \\
\hline Nebulizer & Burgener MiraMist high solids nebulizer (0.4-2.0 mL/min) \\
\hline Spray chamber & Glass cyclone \\
\hline Plasma torch & Enhanced matrix tolerance (EMT) semi-demountable \\
\hline RF power & $1150 \mathrm{~W}$ \\
\hline Pump rate & 50 rpm \\
\hline Auxiliary gas flow & $0.5 \mathrm{~L} / \mathrm{min}$ \\
\hline Nebulizing gas flow & $0.5 \mathrm{~L} / \mathrm{min}$ \\
\hline Number of replicates per sample & 3 \\
\hline Maximum integration time for low WL range & 15 s (both axial and radial) \\
\hline Maximum integration time for high WL range & $10 \mathrm{~s}$ (axial) and 5 s (radial) \\
\hline Flush time & $45 \mathrm{~s}$ \\
\hline
\end{tabular}

\section{Total organic carbon analysis}

Unlike ICP-OES, TOC is a non-specific analysis, which means that it does not determine which particular compounds are present, but, instead, gives information of the amount of organic carbon within the solution [26].

The TOC-V CPH analyser (Shimadzu Schweiz GmbH, Reinach, Switzerland) was calibrated by suitably diluting a $1000 \mathrm{mg} / \mathrm{L}$ TOC standard (by Sigma-Aldrich, produced according to ISO/CEN EN1484) in UPW to have a calibration curve in the range between 0 and $250 \mathrm{mg} / \mathrm{L}$. The reference material had a concentration of $50 \mathrm{mg} / \mathrm{L}$ of TOC, also prepared by diluting the above-mentioned TOC standard solution. For TOC measurements, a part of the filtered solution was diluted with $0.05 \mathrm{M} \mathrm{HCl}$ in 
Table 3 The average, standard deviation, median and the maximum and minimum temperature and $\mathbf{R H}$ values recorded at Hopperstad Stave Church from June to December 2017

\begin{tabular}{|c|c|c|c|c|}
\hline & Inside south & Inside north & $\begin{array}{l}\text { Outside } \\
\text { south }\end{array}$ & Outside north \\
\hline \multicolumn{5}{|c|}{ Temperature $\left({ }^{\circ} \mathrm{C}\right)$} \\
\hline Average & 10.1 & 10.4 & 10.0 & 9.9 \\
\hline Std dev & 5.6 & 5.6 & 5.8 & 5.6 \\
\hline Median & 11.7 & 12.3 & 11.0 & 11.1 \\
\hline Max & 23.2 & 22.2 & 27.6 & 23.1 \\
\hline Min & -6.3 & -5.8 & -6.9 & -6.8 \\
\hline \multicolumn{5}{|c|}{ Relative humidity (\%) } \\
\hline Average & 78.3 & 74.6 & 81.3 & 81.9 \\
\hline Std dev & 10.2 & 8.7 & 13.7 & 13.3 \\
\hline Median & 80.3 & 76.3 & 84.0 & 84.7 \\
\hline Max & 97.8 & 91.5 & 100 & 100 \\
\hline Min & 28.7 & 27.9 & 24.7 & 25.0 \\
\hline
\end{tabular}

UPW to fit in the above-mentioned calibration range of the TOC analyser.

\section{Nitrates and nitrites test}

Strip tests (MQuant, Merck) were carried out on diluted sample solutions used for both the ICP-OES and TOC analyses to possibly determine (and semi-quantify) the presence of nitrates $\left(\mathrm{NO}_{3}^{-}\right)$and nitrites $\left(\mathrm{NO}_{2}^{-}\right)$ions.

\section{Results and discussion}

\section{Climatic monitoring with data loggers}

The average, median, maximum and minimum temperature and $\mathrm{RH}$, as obtained from the data loggers at Hopperstad Stave Church, are presented in Table 3. Data was recorded from 27 June to 10 December 2017 for a total of 4008 readings. Even though the monitoring time was limited, the loggers provided information about the weather changes from summer to the beginning of winter at Hopperstad. The differences in temperature between the southern and northern side, or between the inside and outside of the church (Table 3) cannot explain the formation of the white layer on the southern side. However, the maximum temperature on the outside indicates that the southern side gets warmer than the northern side, with a difference of $4.5^{\circ} \mathrm{C}$. This is because the southern side of the church is more exposed to direct sunlight than the northern side. The inside of the church does not seem to be much affected by this difference. The minimum temperatures were more or less the same on both sides. This indicates that the warmth of the sun has some impact on the southern side even under the gallery. The $\mathrm{RH}$ was high (approximately $80 \% \pm 10 \%$ ) throughout the whole experimental acquisition. The maximum $\mathrm{RH}$ values from the inside did not reach $100 \%$ as on the outside (Table 3 ). The relatively high standard deviations imply large fluctuations in $\mathrm{RH}$, which were expected, since the sensors were placed outside and there is no heating system or isolation inside the church.

\section{Physico-chemical characterization of the white substance Portable X-ray fluorescence}

Figure $5 \mathrm{a}-\mathrm{k}$ show pictures of the XRF measurement locations at Hopperstad Stave Church.

All the spectra (Fig. 6) showed peaks of silicon, sulfur, chlorine, potassium, calcium and iron.

Most of the spectra did not have significantly intense peaks of silicon and sulfur, except four measurements carried out on the white layer on a bench inside the church (e.g., measurement 106). While silicon is a very common element in nature, present in sand and quartz [27], sulfur has different origins and can be an indicator of pollution on works of art [16]. All the other detected elements can be attributed to a variety of sources, including the wood itself. Chlorine, sulfur, potassium, and calcium can, for instance, be found in the secretion of human sweat and they can also be present in varnished wood [28].

Iron is also one of the inorganic components of wood [29]. The iron peaks in the spectra from the outside of the church (i.e., measurements 111, 113, 117, 118 and 119) were a little more intense than those recorded on the inside, which could be due to the presence of wrought iron in proximity of the measuring points.

Phosphorus was also present in several spectra. However, the most intense peaks are present in measurements 120 and 121 (taken near the floor). In fact, on the floor, several types of particles accumulate, possibly from the visitors and/or animal activity, such as rodents.

Particular attention should be given to the presence of chlorine in the spectra of the white surfaces acquired on the southern exterior side of the church (i.e., measurements 113 and 119). The intensity of chlorine peaks decreased similarly to the calcium ones. This could indicate the presence of calcium chloride, $\mathrm{CaCl}_{2}$. However, calcium chloride is also very water soluble and is not likely the origin of the white layer, since the salt would have been dissolved at the high recorded $\mathrm{RH}$ values (deliquescence humidity of $\mathrm{CaCl}_{2}$ at $0{ }^{\circ} \mathrm{C}: 44.3 \%$ ) [12].

Intense sulfur peaks were observed in the spectra from measurements 106, 120, 125 and 126. The peaks in these spectra are correlated with strong calcium ones, thus pointing to the possible presence of calcium sulfate $\left(\mathrm{CaSO}_{4}\right)$. This is also a white powdery material, commonly known as gypsum $\left(\mathrm{CaSO} 4 \cdot 2 \mathrm{H}_{2} \mathrm{O}\right)$ when hydrated. However, gypsum has a relatively low 


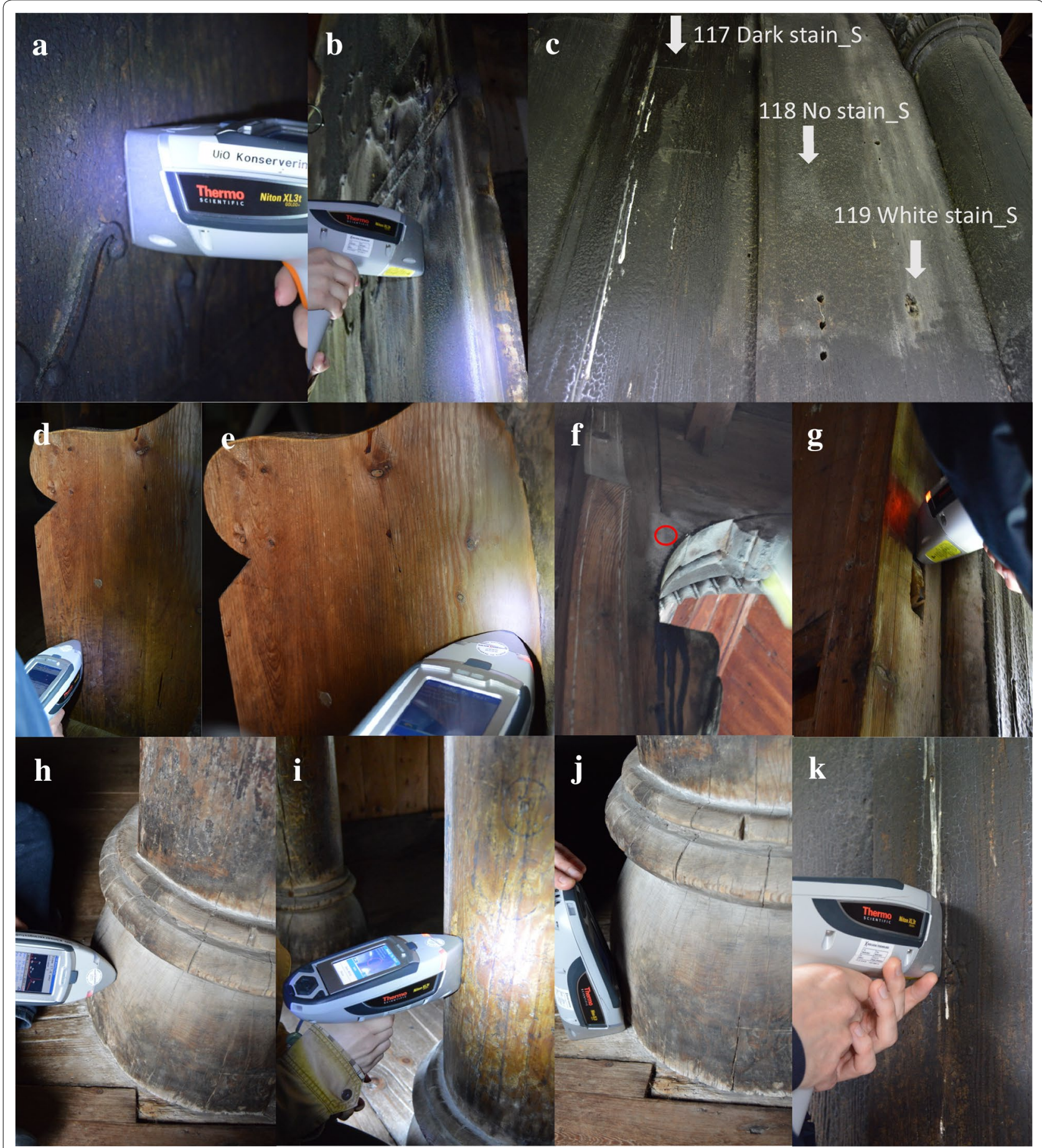

Fig. 5 Locations of the XRF measurements. a Measurement 111 with no white substance and $\mathbf{b}$ measurement 113 with white substance were taken on the southern exterior door. c Measurements 117, 118 and 119 (marked with white arrows) on the exterior wall left of the southern entrance with staining. $\mathbf{d}$ Measurement 110 with no white substance and $\mathbf{e}$ measurement 106 with white substance were taken on the bench inside the church. $\mathbf{f}$ Measurement 125 was taken on the white substance on the wall by the entrance (marked with a red circle). $\mathbf{g}$ Measurement 126 was taken on the white substance on the crossbar. $\mathbf{h}$ Measurement 120 was taken on the stave base with a white substance. $\mathbf{i}$ Measurement 122 was taken on the stave without a white substance and $\mathbf{j}$ Measurement 121 was taken on the floor with a white substance. $\mathbf{k}$ Measurement 116 was taken on the bird droppings 


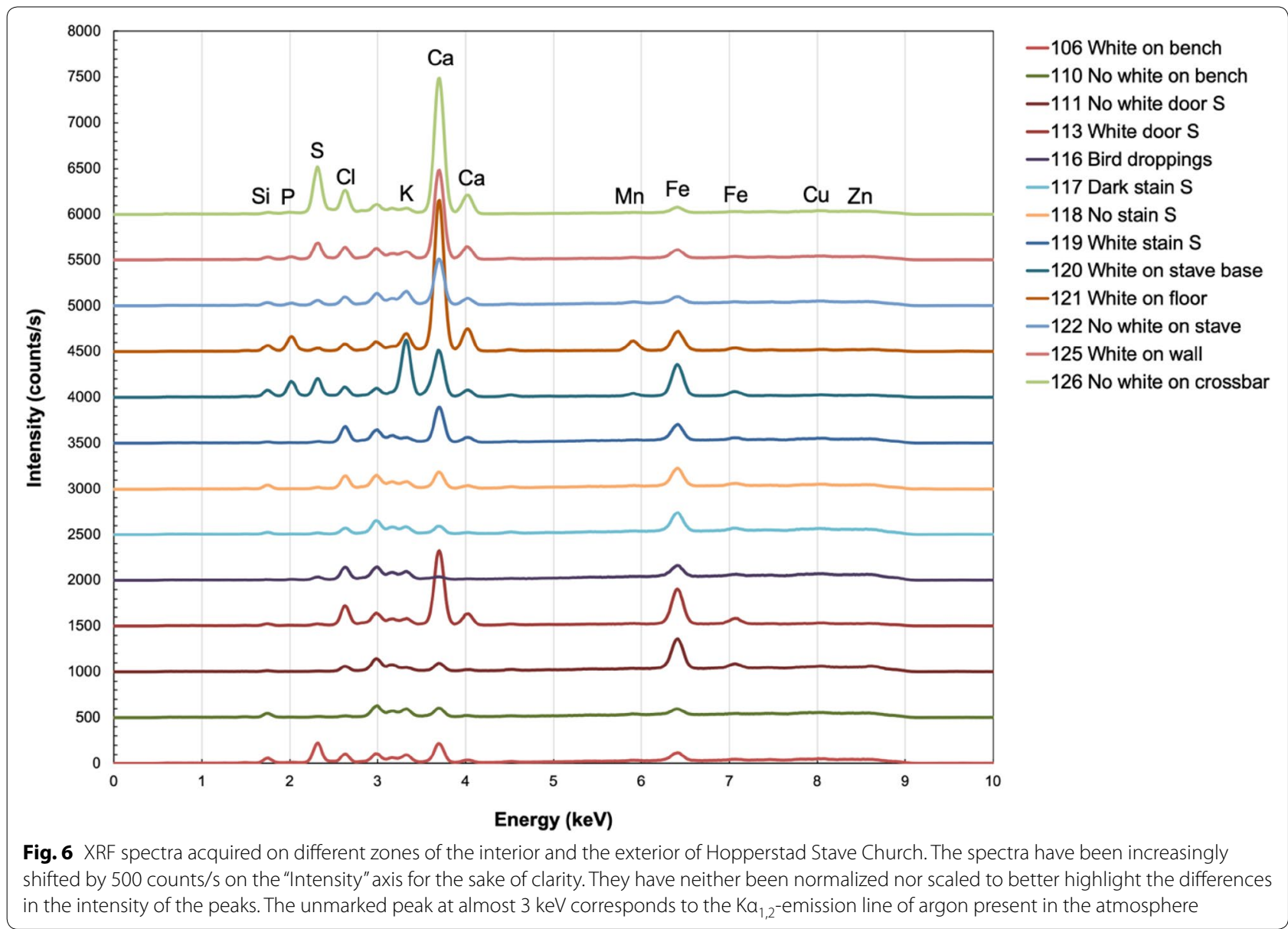

solubility when it dries [12], and the white substance on Hopperstad was water-insoluble.

The remaining element that is worth of consideration is calcium. The results showed that there were significant differences in the intensity of calcium peaks between the measurements taken on areas with and without a white layer, and this was more or less consistent in all the measurements. For example, the spectra from the areas featuring the white substance on the southern door show calcium peaks that are around 8-9 times more intense than those in the spectra of the surfaces without the white substance (e.g., measurement 111). Similar results in terms of difference in the intensity of the calcium peaks are obtained from the spectra acquired inside the church.

The only spectrum without a significantly intense peak of calcium was the one recorded on the bird droppings (i.e., measurement 116).

The low peak of calcium indicates that the white layer is not related to the bird droppings. There was presence of phosphorus, but not as intense as in some of the other measurements on, for example, the stave base and floor inside the church (i.e., measurements 120 and 121). The presence of phosphorus confirms animal origin [30]. There were also intense peaks of chlorine, potassium and iron, along with tiny peaks that indicated the presence of copper and zinc. Zinc is a common element in nature and is present in biological materials, for instance in human sweat $[28,31]$.

\section{Scanning electron microscopy}

It was possible to observe some crystalline structures in the SEM images of the sample fragments with a white layer from Hopperstad Stave Church. The shapes of the crystals in some of the micrographs could correspond to those of calcite, for instance, the crystals on the samples from the floor and crossbar (Fig. 7b-d) inside the church. The micrographs of the samples with a white layer were substantially different from the ones of the bird dropping sample (Fig. 7a). The whole surface of the studied bird dropping sample had rounded formations, which indicate organic material. Similar rounded formations were only 


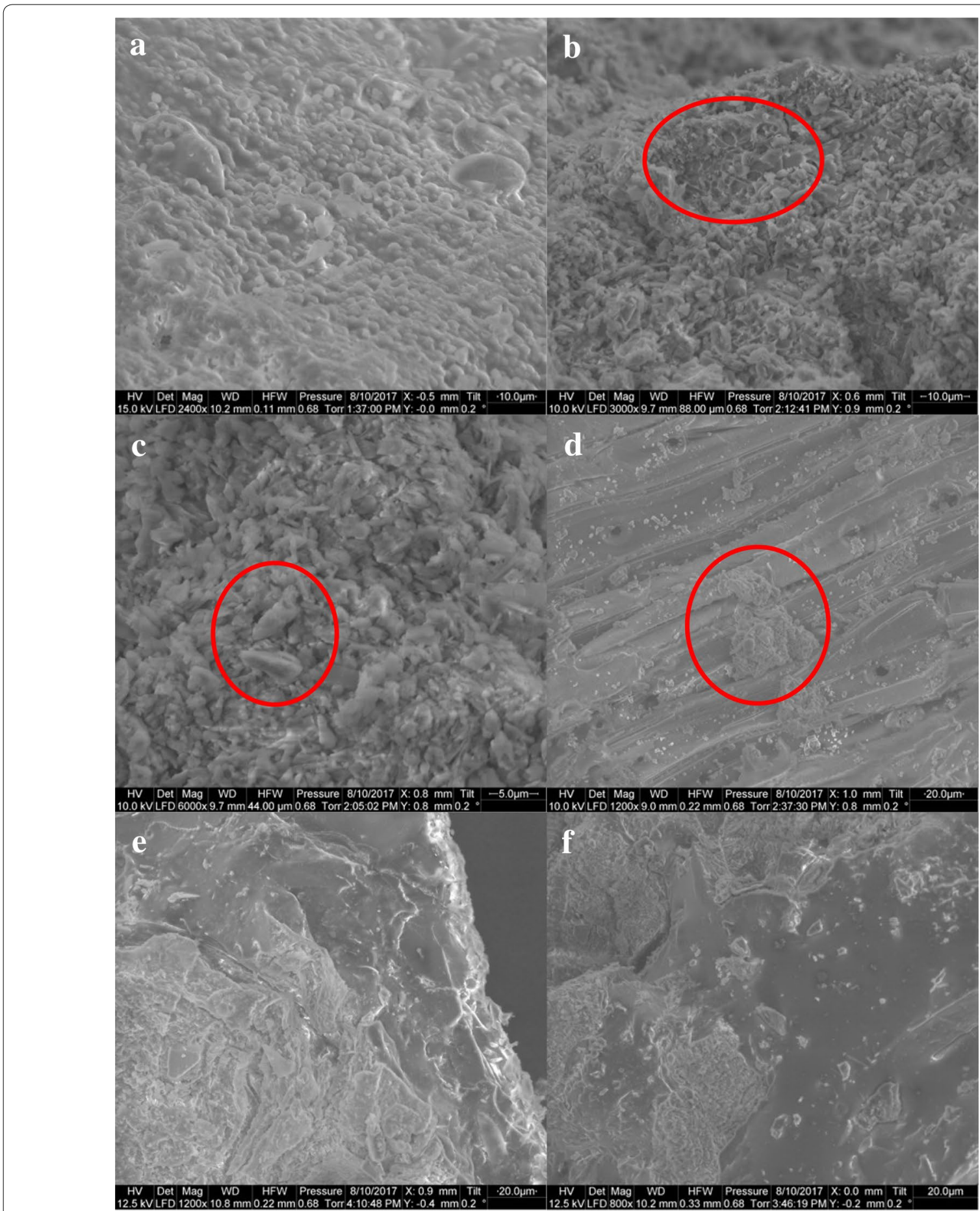

Fig. 7 SEM micrograph of the bird dropping sample (a), from the floor $(\mathbf{b}, \mathbf{c})$, crossbar (d), the southern exterior door (e) and the portal above the southern entrance ( $\mathbf{f}$ ). The flake-like structures are marked in $\mathbf{b}$ and the triangular crystals are marked in $\mathbf{c}$. A cluster that could be a mixture of organic and inorganic particles is marked in $\mathbf{d}$

seen in some areas of the samples with white layer. These areas differed from the crystalline particles by being clustered together and could be a mixture of organic and inorganic particles (Fig. 7d). It was expected to find such mixture on the sample fragments since these came from an open-air environment. 
All the samples from the exterior of the church had quite similar appearance. The sealing effect of the tar on wood could be seen clearly on these samples, especially if compared with the samples from the inside where the wood structure was very visible. A variety of particles and formations featuring unclearly defined shapes on the exterior samples, probably both organic and inorganic, were present. The surface of the tar appeared cracked and no crystals were present in the cracks (Fig. 7e, f). The white layer seemed to follow the cracking pattern of the tar. The samples from the inside of the church had more clearly visible crystalline particles on the wood. Most of these crystals appear to have clearly defined edges and triangular shapes. Some distinct differences were visible in the samples from the floor near the stave base and the crossbar. The particles observed on the crossbar sample (Fig. 7d) were scattered on the surface, so the wood structure was very visible, while, on the sample from the floor (Fig. 7b, c), the particles were more packed together and concealed the wood underneath. There was also an area in the sample from the floor that featured flake-like structures, probably attributable to clays. Particles accumulated more easily on the floor than higher up on the wall. This could explain the different appearance of the micrographs of the samples. Even though the particles on the floor were more packed together, some of the crystalline structures were more easily recognizable than on the exterior samples. For instance, some triangular shaped crystals could clearly be seen. The reason that the crystals on the inside were more defined could be that the particles on the exterior are more exposed to the outside climate. When the $\mathrm{RH}$ varies, crystallization cycles can occur [12, 32]. The crystals on the outside might dissolve and recrystallize more often than on the inside. This was also suggested by the SEM images. When the RH drops down, salts precipitate and crystallize, whereas when the $\mathrm{RH}$ rises, previously crystallized salts can re-dissolve [33]. The crystals on the outside of the church appeared to have reformed on top of each other and created a layer with "several generations of crystals". The data from the climatic monitoring showed that the RH was frequently high and that many fluctuations occurred. It was also possible to see in the SEM micrographs that the observed particles appeared to be only located on the surface of the sample fragments. It was not possible to see that on the sample from the floor. This means that the particles-including those from the white layer both on the inside and outside of the church-most probably have deposited on the surface and did not migrate from within the wood or were a degradation product of the tar. This statement is supported by the observation that no visible particles in the wood structure (pores and resin channels) were present and the particles were rather on top of the smooth surface of the tar. However, the possibility for the salts to migrate inside the wood should also be mentioned.

\section{Inductively coupled plasma-optical emission spectrometry} The ICP-OES results are presented in Fig. 8 below, where we report, for each single element, the content given by the wavelength line with the lowest closeness of agreement (namely, best trueness). Table 4 shows the analytical figures of merit of the used method. The results from the measurements on the sample solutions supported the results obtained from the XRF analysis. All the samples with white layer (M4-M7) had high amounts of calcium. Results from the bird dropping sample (M1) show different amounts of several other elements, which means that it had another elemental composition when compared with the samples featuring the white layer. It can, therefore, be concluded that the white layer is probably not caused by the bird droppings. Due to challenges during preparations of the samples, the samples from the inside of the church were not characterized by ICP-OES. Calcium is not usually found in tar, which means that this element should come from the white layer.

Sample M6, from the exterior southern door, had a significantly higher amount of calcium than the rest of the samples. As seen in Fig. 8, it actually exceeded the possible amount in solution. It had, in fact, a higher amount of all the elements than the other samples with white layer. The amount of calcium was higher than the mass of the samples, which comes from the very high uncertainty on the weighed mass. In fact, it was not even possible to weigh some of the taken samples (due to their extremely low mass and/or electrostatic interaction). This is the reason why the standard deviations were not plotted.

\section{Total organic carbon analysis}

The TOC analysis was a complementary test to the other analytical methods. The results are shown in Fig. 9. Only samples of the exterior were analysed with the TOC (the same sample solution used for the ICP-OES analysis). The results confirmed that the bird droppings have animal origin by having a high amount of organic carbon. All the samples with white layer had a low amount of organic carbon compared to the bird dropping sample. This evidence indicates that the content in these solutions was mainly inorganic. This supports the results of the other conducted analyses: the crystalline structures observed with SEM and the high presence of calcium detected by $\mathrm{XRF}$ and ICP-OES analyses. The TOC result proves that bird droppings is not the origin of the white substance. 


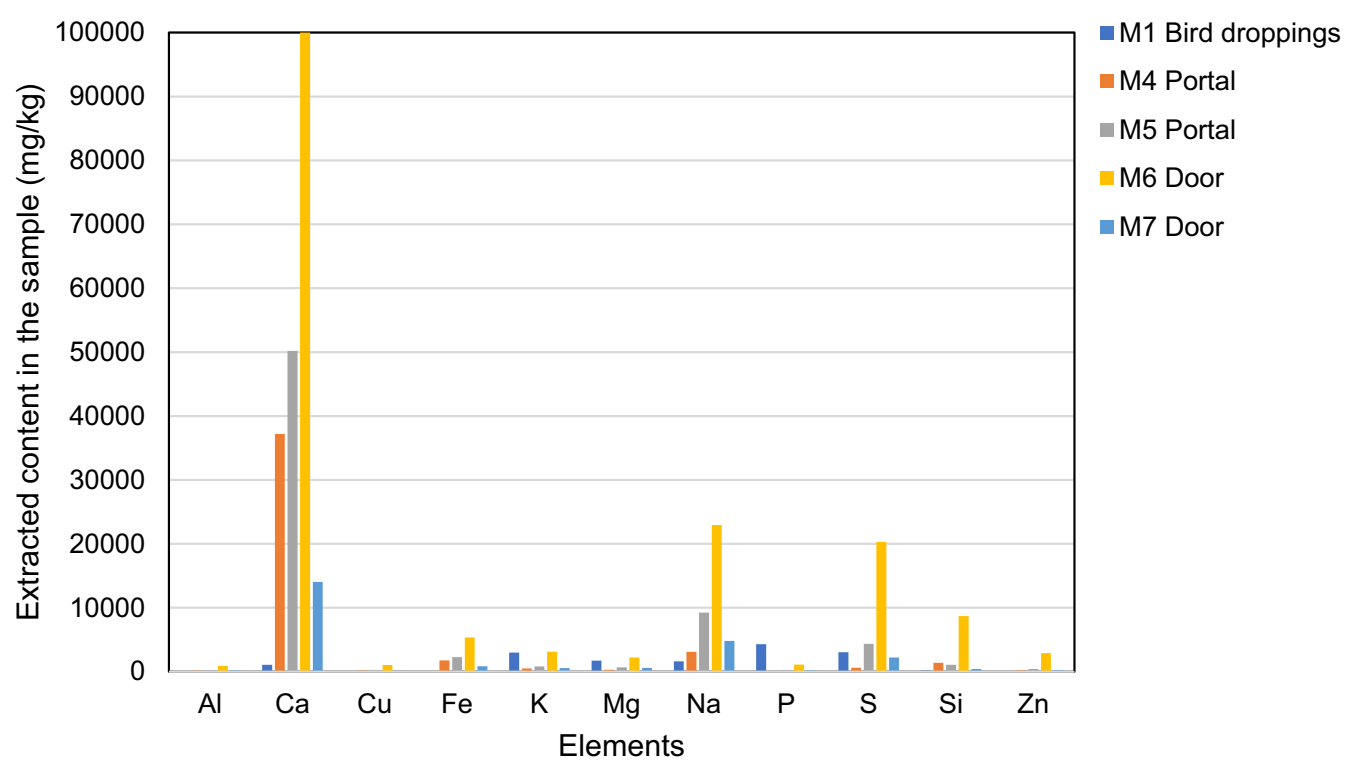

Fig. 8 Extracted content of each element in samples M1 and M4-M7. All the samples from the white substance have a high amount of calcium The bird dropping sample, M1, has a higher amount of phosphorus than the other samples. Sample M6, from the exterior door, has a higher amount of all the elements, compared to the other samples with white layer

Table 4 Measures of closeness of agreement, LODs and LOQs obtained with the proposed ICP-OES method

\begin{tabular}{|c|c|c|c|c|}
\hline Element & Selected spectral line (nm) & Closeness of agreement (\%) & Limit of detection (LOD) $(\mu \mathrm{g} / \mathrm{L})$ & $\begin{array}{l}\text { Limit } \\
\text { of quantification } \\
(L O Q)(\mu \mathrm{g} / \mathrm{L})\end{array}$ \\
\hline \multirow[t]{3}{*}{ Al } & 167.079 & 9.3 & 3.0 & 10.0 \\
\hline & 308.215 & 5.3 & 2.4 & 8.2 \\
\hline & 396.152 & 5.0 & 3.0 & 10.0 \\
\hline \multirow[t]{2}{*}{$\mathrm{Ca}$} & 317.993 & 4.0 & 9.0 & 30.0 \\
\hline & 318.128 & 5.0 & 12.2 & 40.8 \\
\hline $\mathrm{Cu}$ & 324.752 & 1.7 & 1.2 & 3.9 \\
\hline $\mathrm{Fe}$ & 259.940 & 1.3 & 3.0 & 10.0 \\
\hline \multirow[t]{2}{*}{ K } & 766.490 & 1.1 & 6.0 & 20.0 \\
\hline & 769.896 & 0.2 & 13.5 & 45.0 \\
\hline $\mathrm{Mg}$ & 279.079 & 3.3 & 1.5 & 5.0 \\
\hline $\mathrm{Na}$ & 589.592 & 3.6 & 1.5 & 5.0 \\
\hline$P$ & 178.287 & 1.0 & 1.5 & 5.0 \\
\hline S & 182.034 & 1.7 & 3.8 & 12.6 \\
\hline \multirow[t]{2}{*}{$\mathrm{Si}$} & 251.611 & 4.0 & 4.2 & 14.1 \\
\hline & 288.158 & 4.0 & 1.5 & 5.0 \\
\hline \multirow[t]{3}{*}{$\mathrm{Zn}$} & 202.541 & 3.3 & 1.5 & 5.0 \\
\hline & 206.200 & 3.0 & 1.5 & 5.0 \\
\hline & 213.856 & 2.0 & 1.5 & 5.0 \\
\hline
\end{tabular}

The value was computed as the mean (the measurement was repeated three times) percentage deviation from the expected value for an independently prepared RM. The selected spectral lines allow covering the range of concentrations of the samples in this work. Also reported are the LODs and LOQs ( $\left.n_{\text {blanks }}=4\right)$. The plasma viewing for all the lines is axial

\section{Nitrates and nitrites test}

The results related to nitrate and nitrite strip tests are shown in Fig. 10.
The amount of both nitrate and nitrite ions in the sample solutions is below the LOD of the strips $(10 \mathrm{mg} / \mathrm{L})$. Nitrate is an important contaminant in surface soils, 


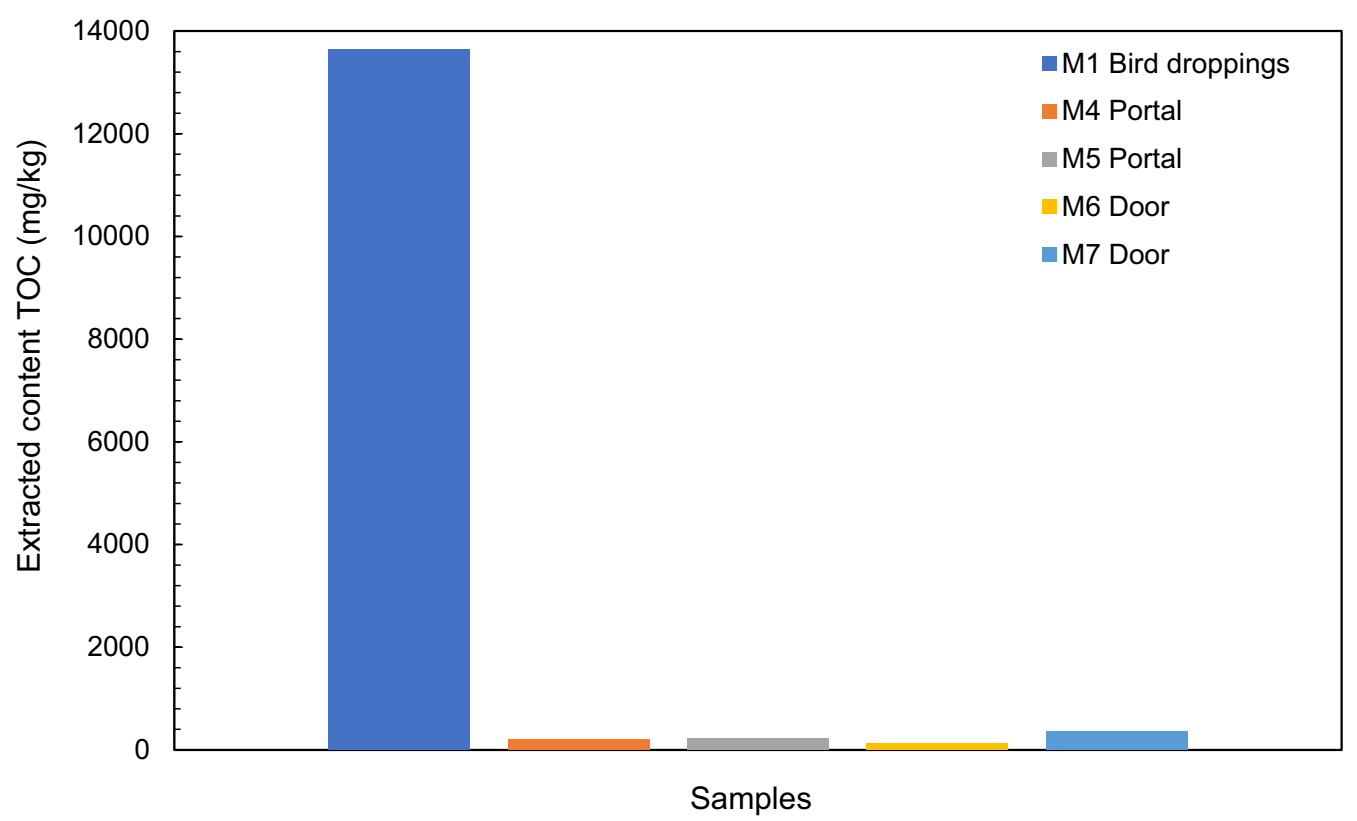

Fig. 9 TOC results of the extracted sample solutions

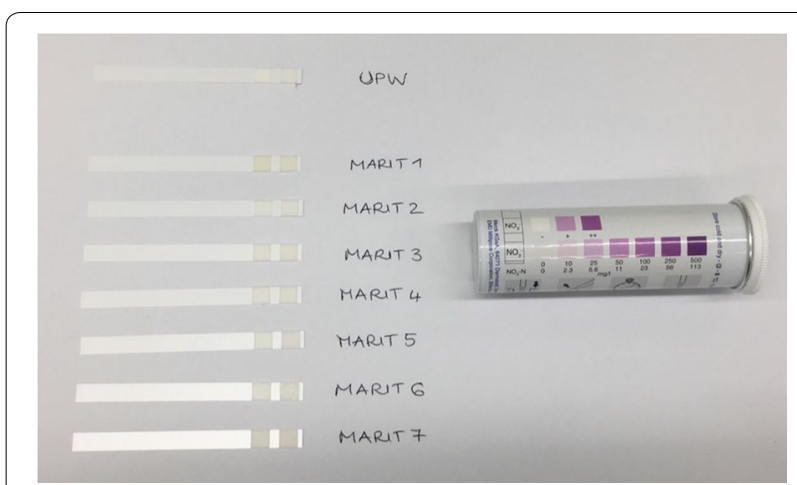

Fig. 10 Results from the nitrate and nitrite test of the extracted and filtered sample solutions. The presence of the ions is indicated by a purple tone on the strips. UPW was used as a reference

originating from the use of fertilizers, animal waste, and the oxidation of organic nitrogen [12]. According to Arnold and Zehnder [33], soils in proximity of human housings and settlements are especially enriched in nitrate and chloride, compared to the normal soils, as nitrate being produced by microorganisms from organic wastes, and chlorides being supplied by the consumption of sodium chloride. Since none of the ions were detected by the strips, it means that the origin of the white layer is not nitrate-containing compounds, thus excluding the above-mentioned sources.

\section{Evaluation of potential sources and causes for the phenomenon}

Although some of the main elements of the white substance are known, it is difficult to conclude with certainty what the source and cause of the phenomenon are. The origin of the formation of the white substance can be different from what is causing it to evolve and spread. In addition, it is indicated by the results from the conducted analyses that the layers could be different on the inside and outside of the church. The results from the analyses have enabled to exclude some possible causes and sources or to consider them as unlikely for the formation of the layer. In fact, almost all the suggestions made before the analyses can be eliminated.

The high presence of calcium, as quantified by ICP-OES, possibly excluded degradation products of tar as causes for the white layer. Since the layer is mainly inorganic, as resulted by the low content of TOC, biological growth could also be ruled out. Precipitation of salt efflorescences from pesticides was also excluded, mainly because SEM analyses evidenced that the white layer has been deposited on surfaces, both inside and outside the church. Besides, the chemical composition of the white layer did not indicate that its origin is from pesticide treatments. 


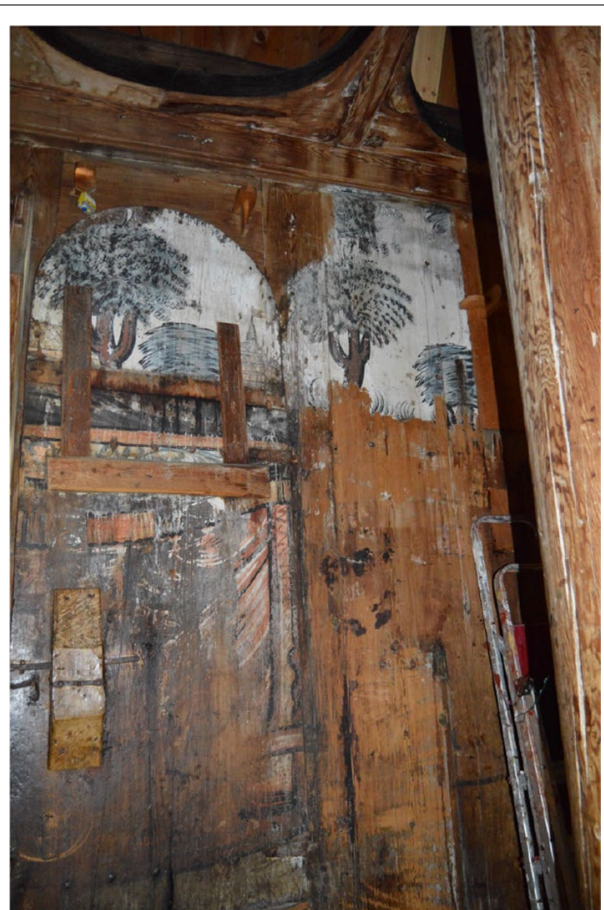

Fig. 11 Glue paint on the interior of the southern door and wall

Moisture (high RH) and local leakages cannot be completely excluded as well, even though this is also unlikely, mainly because the phenomenon should have been observed on other parts of the church. They can, however, have contributed to the spread of the layer to the exterior. Leakages from the copper-based sprinkler system, which runs all around the church's exterior under the gallery, have also been considered as an unlikely cause because higher amounts of copper should have been present in the sample solutions analysed by ICP-OES. In addition, none of the XRF measurements showed intense signals related to copper. Corrosion products from the metal on the exterior door were considered as a possible cause for the white layer, since most of the substance is localized around some of the metal on the door. In some areas, it also looks like the substance has moved downwards from the metal. However, also this theory has been ruled out since there is a layer of white substance on the portal above the door as well. The results from the TOC analyses also exclude the presence of water-soluble organic salts (e.g., formates and acetates) in the white substance.

Remains from the medieval glue paint ${ }^{3}$ on the interior southern door (Fig. 11) were also excluded as source of the formation based on the conducted analyses, but they could have affected the results of the chemical analyses from the inside of the church.

Chalk was commonly used as pigment in glue paint. It was often used as background colour in the churches in the Middle Ages [34, 35]. The XRF spectra did not show any significant decrease of the calcium peaks between the areas with a white layer on the stave base and those without a layer higher up on the stave that was observed in all the other comparisons. The XRF spectra of the bench showed low-intensity calcium peaks in areas without a white layer. The bench is, however, not original from the Middle Ages and was placed in the church by Blix during the restorations in the 1880s. It is not certain whether the bench was painted or not. It is not likely that the ions constituting chalk migrated from within the wood out to the surface and that, as a consequence, this be the origin of the visible white layer, mainly because it should have been observed on several parts of the church.

\section{Potential sources from the surrounding environment at Hopperstad}

Since the layer is locally formed on the southern side of the church, and it appears to be only on the surface, the source and cause of the white layer are probably atmospheric. The results from the chemical analyses indicate that the salt is most likely calcium carbonate. However, it is still unknown how it deposited and what caused its diffusion. A combination of different factors could have caused the formation of the layer. Such a combination could be different for the layers on the inside and outside of the church. There are generally several possibilities how salts can be brought into buildings: from air pollution, sea spray, atmospheric chemical reactions, reconstructions and renovations, de-icing agents, or rising damp [12, 36, 37].

Although the search of potential sources and causes has somehow been narrowed by knowing that calcium is one of the main elements, the confined area of the white layer on the southern side makes it difficult to unambiguously find the reason for its formation. For instance, chalk (lime) is often used in agriculture to increase the $\mathrm{pH}$ in the soil [38]. It can also be used on lawns for the same purpose, thus contributing to plant growth. Whether the lawn around Hopperstad is being chalked is unknown. Dust, soil and particles (among others) containing chalk could have deposited from the nearby fields, lawns or from the graveyard by the church with the wind. However, if this was the cause for the formation of the white layer, the latter should have been observed on other parts of the church. In addition, most calcium-containing fertilizers also contains nitrates, which were not detected by the strip tests. Fertilizers were, as a consequence, excluded as a potential cause.

\footnotetext{
${ }^{3}$ Glue paint is a water-based paint made with pigments and an animal glue as main binder. The type of glue and the additives added to the binder most likely varied, depending on what was available at the time and what the individual painter preferred [34].
} 


\section{Assessment of the harmfulness for the church's materials}

Salt weathering of buildings is a highly complex process and there are many factors that play a role: the salt-containing solution, the type of salt, environment, the different properties of the substrate, and the thermodynamics and kinetic factors [39]. Certain types of salt can cause more damage than others to different materials. Knowing the chemical composition of the salt is, therefore, only one of the important factors necessary to assess the true harmfulness it might have on the materials [11]. The layer on Hopperstad Stave Church could possibly be harmful for the wood and metal in the long term, especially when the materials are unprotected by the tar. Salts, when in aqueous solution, can enter and move through porous materials thanks to capillary forces [36, 39]. Salts inside building materials can absorb environmental moisture and dissolve. When water evaporates, the salt crystallizes and can cause crystallization pressure inside the building material. During salt crystallization growth, high stresses can arise even in large pores in the materials, especially if the growing crystals are confined [12, 32, 36, 40-42]. Other damaging mechanisms can take place, too. However, Feilden states that calcium carbonate in itself is believed not to have a disintegrating effect once it has crystallized. It rather forms incrustations that are very hard and intractable [43]. In fact, a study from the Vasa Warship suggests that calcium carbonate may even have a preserving effect on the wood by stabilizing it and prevent damage caused by sulfuric acid [44].

Metal corrodes by oxidation, in the presence of water, oxygen and other contaminants on the metal surface [45]. Although salts are generally known to increase the corrosion rate on metal, the latter also depends on the type of salt. For instance, soluble chlorides are highly corrosive for metals [37]. Despite the fact that chlorides were detected by the elemental analysis of the white substance, the corrosion rate of the wrought iron on the southern door at Hopperstad does not seem to be particularly fast, considering that part of the metal is exposed to the environment due to wearing of the tar.

The white layer does not seem to impose an immediate threat to the materials. Although the layer has been present on the exterior surface for at least 9-10 years and no visible harm has occurred, concerns may be raised because the full elemental composition of the salts is not known, as well as how it will continue to evolve in the future. The substance may react in different ways with the present pronounced climate change [46]. The climate at Hopperstad has recently been assessed by NIKU (on request by $\mathrm{RA}$ in relation to the "Stave Church Preservation Program") ${ }^{4}[6,47,48]$. Increased rainfall and moisture damage caused by mold growth and leakages were some of the concerns about the future climate at
Hopperstad. If the calcium-containing salts on Hopperstad Stave Church contribute to maintain moisture on the surfaces in an even wetter climate, they could possibly inflict severe moisture-related damage. It is believed that a contributing preservation effect that have led to the preservation of the remaining stave churches in Norway is, in fact, the dry inland climate [49]. However, so far, it seems that this phenomenon is mainly an aesthetic issue.

Even though the chemical composition of the white substance is partly identified and some of the potential harmfulness it might have on the church's materials is assessed, it is still not clear what the source and cause of the phenomenon actually are. Therefore, a proper solution for removing the layer-ensuring that it does not appear again-is also hard to propose. Even if the layer does not cause any immediate damage to the church's materials, it is still aesthetically unpleasing, especially on the exterior, and its removal should be considered. Definitive recommendations on whether the layer on the inside of the church should be removed or not cannot be given, on the basis of the results of this research. These layers are not as visible as on the exterior and is, therefore, not an aesthetical issue to such a degree as it is on the exterior.

\section{Conclusions and outlook}

The physico-chemical characterization of an unidentified white substance on parts of the southern side of Hopperstad Stave Church has been the focus of this study. The white substance was observed on both the exterior and the inside of the church. Non-invasive analysis with portable XRF and invasive analyses on micro-samples $(\leq 1 \mathrm{mg})$ with SEM, ICP-OES, TOC and nitrite and nitrate strip tests were conducted. The results showed that the white substance has a high content of calcium and mainly consists of inorganic matter, that it is crystalline and appears to only be on the surface of the wood and tar. Although the full elemental composition has not yet been identified, the results from the analyses that have been performed in this study show that the salt formation is likely to be calcium carbonate.

To further corroborate this hypothesis, on a microsample coming from a second sampling campaign (not part of this research), taken from the upper right side of the door, a semi-micro qualitative test with hydrochloric acid [50] was conducted under the stereomicroscope. Effervescence was clearly visible on the surface of the micro-sample.

\footnotetext{
${ }^{4}$ The Stave Church Preservation Program was initiated by RA in 2001 to restore all the stave churches in Norway [47].
} 
Based on this and due to the confined location of the substance on the southern side of the church, some potential causes and sources for the phenomenon could be excluded: microbiological growth, precipitation of pesticides, degradation products of tar, fertilizers and animal origin (bird droppings). It is believed that the source for the white substance is atmospheric. The white substance is harmful for neither visitors nor the environment. Although the layer has been present for several years on the church's surfaces, especially on the exterior, there were no signs of critical degradation of the church's materials, either on the wood or metal, which could be directly linked to the presence of the white layer. It is not believed that the substance poses an immediate threat to the building materials, but concerns are raised for how it can potentially change in the future and possibly inflict damage on the materials in the long term. The layer has an aesthetical unpleasing appearance on the exterior door and portal, and for that reason, removal of the layer should be considered.

With sufficient sample mass, X-ray diffraction could provide an almost definitive answer about the nature of the white substance. FTIR (laboratory and handheld) and $\mathrm{CHN}$ analyses would also contribute.

Although there are still unanswered questions regarding the white layer, this research (featuring only micro-sampling) has provided information and insight that are beneficial to the preservation of an important part of Norway's cultural heritage. Hopperstad Stave Church is a unique, non-replaceable historical site and is worth preserving for the future.

\section{Abbreviations}

RA: The Norwegian Directorate for Cultural Heritage (Riksantikvaren); XRF: portable X-ray fluorescence; SEM: scanning electron microscopy; ICP-OES: inductively coupled plasma-optical emission spectrometry; TOC: total organic carbon analysis; RH: relative humidity; LOD: limit of detection; UPW: ultrapure water.

\begin{abstract}
Acknowledgements
The authors are grateful to Leif Anker and Kjersti Marie Ellewsen, from the Norwegian Directorate for Cultural Heritage (RA, Riksantikvaren); Merete Winness from the National Trust of Norway (Fortidsminneforeningen); Kari W. Sunde and Berit Bolstad, keepers of Hopperstad Stave Church; and Inger M. Egenberg, from the Archaeological Museum at the University of Stavanger. They all gave valuable information about Hopperstad Stave Church's history and conservation issues.
\end{abstract}

\section{Authors' contributions}

ML, FC and SM designed the research. All authors performed the experiments. All authors contributed in analyzing the data and writing the paper. All authors read and approved the final manuscript.

\section{Funding}

Not applicable.
Availability of data and materials

Raw data is available from the authors on request.

\section{Competing interests}

The authors declare that they have no competing interests.

\section{Author details}

${ }^{1}$ Institutt for arkeologi, konservering og historie (IAKH), Conservation Studies, Universitetet i Oslo (UiO), Blindern, Postboks 1008, 0315 Oslo, Norway. ${ }^{2}$ Institut für Baustoffe (IfB), Physical Chemistry of Building Materials, ETH Zürich, Stefano-Franscini-Platz 3, HIF B64.2 and C17.1, 8093 Zurich, Switzerland.

${ }^{3}$ Abteilung Kunsttechnologie, Schweizerisches Institut für Kunstwissenschaft (SIK-ISEA), Zollikerstrasse 32, 8032 Zurich, Switzerland.

Received: 19 June 2019 Accepted: 30 September 2019

Published online: 08 October 2019

References

1. The Stave Churches. https://www.riksantikvaren.no/en/Topics/The-Stave -Churches. Accessed 18 June 2019.

2. Urnes Stave Church. https://whc.unesco.org/en/list/58. Accessed 18 June 2019.

3. Riksantikvaren. Rapport: Hopperstad stavkyrkje. Dokumentasjon av stavkyrkjeprogrammet. 2016. p. 3-11. http://hdl.handle.net/11250/24211 17. Accessed 18 June 2019

4. Mehlum S. Et bevaringsprogram for stavkirkene i Norge: stavkirkeprogrammet 2001-2015. In: Bakken K, editor. Bevaring av stavkirkene: håndverk og forskning. Oslo: Pax forlag; 2016. p. 23-46.

5. Anker L. A-291 Hopperstad stavkirke-konservering og tilstandsovervåking. [Internal report]. 2013.

6. Olstad TM, Haugen A. Hvorledes sikre og forvalte norske kirkebyninger i fremtidens klima. NIKU oppdragsrapport: Hopperstad stavkirke; 2016.

7. Devold EM. Befaringer Hopperstad stavkirke 29.11.01 og 25.11.03 stavkirkeprogrammet. [Report]. 2003.

8. Devold EM. Hopperstad stavkirke 18.11 .05 stavkirkeprogrammet befaring. [Report]. 2005.

9. Anker L. Hva er en stavkirke? In: Bakken K, editor. Bevaring av stavkirkene Håndverk og forskning. Oslo: Pax forlag; 2016. p. 17-23.

10. Egenberg IM, Aasen JAB, Holtekjølen AK, Lundanes E. Characterisation of traditionally kiln produced pine tar by gas chromatography-mass spectrometry. J Anal Appl Pyrol. 2002;62(1):143-55.

11. Catelli E, Bănică F-G, Bănică A. Salt efflorescence in historic wooden buildings. Herit Sci. 2016;4(1):31.

12. Steiger $M$, Charola $A E$, Sterflinger K. Weathering and deterioration. In: Stone in architecture: properties, durability. 5th ed. Berlin, Heidelberg: Springer; 2014; p. 225-317.

13. Knatterød P. Rentokil. Skadedyrbekjempelse - Hygienevirksomhet - Husbukk - Hussoppbekjempelse. [Report]. 1984.

14. Artioli G. Scientific methods and cultural heritage: an introduction to the application of materials science to archaeometry and conservation science. Oxford: Oxford University Press; 2010.

15. Brunetti B, Miliani C, Rosi F, Doherty B, Monico L, Romani A, et al. Noninvasive investigations of paintings by portable instrumentation: The MOLAB Experience. Top Curr Chem (Z). 2016;374(10):2016.

16. Cesareo R, Ridolfi S, Marabelli M, Castellano A, Buccolieri G, Donativi M, et al. Portable systems for energy-dispersive $X$-ray fluorescence analysis of works of art. In: Potts PJ, West M, editors. Portable X-ray fluorescence spectrometry: capabilities for in situ analysis. Cambridge: RSC Pub; 2008. p. $206-46$.

17. Potts PJ. Introduction, analytical instrumentation and application overview. In: Potts PJ, West M, editors. Portable X-ray fluorescence spectrometry: capabilities for in situ analysis. Cambridge: RSC Pub; 2008. p. 1-12.

18. Stuart B. Analytical techniques in materials conservation. Chichester: Wiley; 2007. 
19. Guthrie JM. Overview of X-ray fluorescence. 2012. http://archaeomet ry.missouri.edu/xrf_overview.html. Accessed 26 Sept 2017.

20. AIC. The code of ethics and guidelines for practice of the American institute for conservation of historic and artistic works (AIC) 1994. http:// www.conservation-us.org/our-organizations/association-(aic)/gove nance/code-of-ethics-and-guidelines-for-practice/code-of-ethics-andguidelines-for-practice-(html)\#.W9hJyRNKho4. Accessed 05 Dec 2018.

21. E.C.C.O. Professional Guidelines (II): code of ethics2003 12.10.2017. http:// www.ecco-eu.org/fileadmin/user_upload/ECCO_professional_guidelines _Il.pdf. Accessed 05 Dec 2018.

22. Kozaris IA, Pavlidou E, Salzer R, Capitani D, Spinella A, Caponetti E. Identification Techniques I. In: Conservation science for the cultural heritage: applications of instrumental analysis. London: Springer; 2013; p. 37-90.

23. MyScope. Scanning electron microscopy: Australian microscopy \& microanalysis research facility (ammrf); 2014. http://www.ammrf.org.au/ myscope/sem/introduction/. Accessed 06 May 2017.

24. Caruso F, Mantellato S, Palacios M, Flatt RJ. ICP-OES method for the characterization of cement pore solutions and their modification by polycarboxylate-based superplasticizers. Cement Concrete Res. 2017;9:52-60.

25. Hill SJ, Fisher A, Foulkes M. Basic concepts and instrumentation for plasma spectrometry. In: Hill SJ, editor. Inductively coupled plasma spectrometry and its applications. 2nd ed. Hoboken: Blackwell Publishing Ltd; 2007. p. 61-93.

26. $\mathrm{HACH}$. The importance of measuring total organic carbon. In: Application: drinking water analysis. Loveland: HACH Company. 2016:1-4.

27. Jørgensen S. Silisium. Periodesystemet. https://www.mn.uio.no/kjemi/ tjenester/kunnskap/periodesystemet/Si/alt.html. Accessed 01 Dec 2018

28. Caruso F, Saverwyns S, Van Bos M, Chillura Martino D, Ceulemans A-E, Valck J, et al. Micro-X-ray fluorescence and the old masters. Appl Phys A Mater Sci Process. 2012;107(1):197-202.

29. Unger A. Conservation of wood artifacts: a handbook. In: Schniewind AP, Unger W, editors. Berlin: Springer; 2010.

30. Pollard AM. Analytical chemistry in archaeology. Cambridge: Cambridge University Press; 2007

31. Mostad A. Sink. Periodesystemet. https://www.mn.uio.no/kjemi/tjene ster/kunnskap/periodesystemet/Zn/alt.html. Accessed 01 Dec 2018

32. Caruso F, Wangler T, Flatt RJ. Easy Illustration of Salt Damage in Stone. J Chem Educ. 2018;95(9):1615-20.

33. Arnold A, Zehnder K. Salt weathering on monuments. In: Zezza F, editor Proceedings of the 1st international symposium "The conservation of monuments in the Mediterranean Basin". Bari: Grafo; 1990; p. 31-58.

34. Olstad TM. "Til Guds ære och kyrkens ornament » : Limfargedekor i stavkirkene. In: Bakken K, editor. Bevaring av stavkirkene: håndverk og forskning. Oslo: Pax forlag A/S; 2016. p. 69-91.

35. Drange T. Gamle trehus: reparasjon og vedlikehold. Aanensen HO, Brænne J, editors. Oslo: Universitetsforlaget; 1980.
36. Delgado JMPQ, Guimarães AS, de Freitas VP, Antepara I, Kočí V, Černý R. Salt damage and rising damp treatment in building structures. Adv Mater Sci Eng. 2016;2016:1280894

37. Thomson G. The museum environment. 2nd ed. London: Butterworths; 1986.

38. Kuhlmann R. Calcium carbonate-a versatile mineral. 2001. In: Calcium carbonate: from the cretaceous period into the 21st century. Birkhäuser Basel. p. 275-311.

39. Flatt RJ, Caruso F, Aguilar Sanchez AM, Scherer GW. Chemo-mechanics of salt damage in stone. Nat Commun. 2014;5:4823.

40. Espinosa-Marzal RM, Scherer GW. Advances in understanding damage by salt crystallization. Acc Chem Res. 2010;43(6):897-905.

41. Scherer GW. Crystallization in pores. Cem Concr Res. 1999;29(8):1347-58.

42. Flatt RJ. Salt damage in porous materials: how high supersaturations are generated. J Cryst Growth. 2002;242(3):435-54.

43. Feilden BM. Conservation of historic buildings. Oxford: Butterworth Architecture; 1994.

44. Giorgi R, Chelazzi D, Baglioni P. Nanoparticles of calcium hydroxide for wood conservation. The deacidification of the Vasa Warship. Langmuir. 2005:21(23):10743-8.

45. Selwyn L. Metals and corrosion: a handbook for the conservation professional; 2004.

46. Walther G-R, Post E, Convey P, Menzel A, Parmesan C, Beebee TJC, et al. Ecological responses to recent climate change. Nature. 2002:416(6879):389-95.

47. The Directorate for Cultural Heritage. https://www.riksantikvaren.no/en/ Topics/The-Stave-Churches/The-Stave-Church-Preservation-Programme. Accessed 20 Aug 2019

48. Haugen A, Bertolin C, Leijonhufvud G, Olstad T, Broström T. A methodology for long-term monitoring of climate change impacts on historic buildings. Geosciences. 2018:8(10):370.

49. Anker L. [Personal communication] 2018

50. Vogel Al. Vogel's qualitative inorganic analysis. 7th ed. Svehla G, editor. Harlow: Longman; 1996

\section{Publisher's Note}

Springer Nature remains neutral with regard to jurisdictional claims in published maps and institutional affiliations.

\section{Submit your manuscript to a SpringerOpen ${ }^{\circ}$ journal and benefit from:}

- Convenient online submission

- Rigorous peer review

- Open access: articles freely available online

- High visibility within the field

Retaining the copyright to your article

Submit your next manuscript at springeropen.com 